\title{
Greenhouse Evaluation of Products That Induce Host Resistance for Control of Scab, Melanose, and Alternaria Brown Spot of Citrus
}

J. P. Agostini, Research Plant Pathologist, Instituto Nacional de Tecnología Agropecúaria, 3384 Montecarlo, Misiones, Argentina; and P. M. Bushong, former Senior Biologist, and L. W. Timmer, Professor, University of Florida, Citrus Research and Education Center, Lake Alfred 33850

\begin{abstract}
Agostini, J. P., Bushong, P. M., and Timmer, L. W. 2003. Greenhouse evaluation of products that induce host resistance for control of scab, melanose, and Alternaria brown spot of citrus. Plant Dis. 87:69-74.

Products that induce disease resistance in plants were evaluated on potted seedlings of rough lemon for citrus scab, caused by Elsinoe fawcettii; grapefruit for melanose, caused by Diaporthe citri; and Dancy tangerine for Alternaria brown spot caused by Alternaria alternata pv. citri. Plants were pruned to a single stem with mature leaves and treated at bud break or various times thereafter. New foliage was inoculated and subsequently evaluated for disease severity. Oxycom, Nutriphite, Messenger, Goemar H11, Serenade, ReZist, ProPhyt, Aliette, Actigard, and KeyPlex were evaluated and compared with benomyl or strobilurin fungicides as standards. Most products reduced disease severity compared with the untreated control, but were less effective than standard fungicides. The most generally effective products were ReZist and Actigard, those that contain or produce phosphorous acid (Aliette and Nutriphite), and a bacterial preparation (Serenade). Oxycom and Messenger controlled scab well in some tests. Products that induce host resistance may be useful for disease control in citrus in an integrated program with standard fungicides.
\end{abstract}

Citrus scab, melanose, and Alternaria brown spot are fungal diseases that reduce the value of citrus fruit for the fresh market. Citrus scab is caused by Elsinoe fawcettii Bitancourt \& Jenk. (anamorph Sphaceloma fawcettii Jenk.), melanose is caused by Diaporthe citri F. A. Wolf (anamorph Phomopsis citri H. Fawc. non (Sacc.) Traverso \& Spessa), and Alternaria brown spot is caused by Alternaria alternata (Fr.:Fr.) Keissl. pv. citri Solel $(17,19,20,25)$.

In Florida, citrus scab affects grapefruit, tangerine and tangerine hybrids, and lemon. This disease rarely reduces yield but causes external blemishes that reduce the value of the crop for the fresh market (17). Conidia of $S$. fawcettii are produced on scab pustules on infected leaves, twigs, and fruit and are dispersed by rain splash. Juvenile tissues are most susceptible to infection and fruit is susceptible to infection for about 6 to 8 weeks after petal fall.

Corresponding author: L. W. Timmer E-mail: 1wt@1al.ufl.edu

This research was supported by the Florida Agricultural Experiment Station and a grant from the Florida Citrus Production Research Advisory Council, Project 023-16P, and approved for publication as Journal Series no. R-08923.

Accepted for publication 28 August 2002.

Publication no. D-2002-1112-01R

(C) 2003 The American Phytopathological Society
Melanose affects all citrus but is most serious on grapefruit for the fresh market. Conidia of $P$. citri are produced on dead twigs in the tree canopy and are rain-splash dispersed to young susceptible leaves, twigs, and fruit (25). Fruit are susceptible to infection until late June or early July in Florida.

Alternaria brown spot affects mostly tangerine and tangerine hybrids (20). This disease can cause fruit drop and reduce yields, but is primarily a fruit blemish disease. Conidia are produced mostly on lesions on mature leaves and are airborne. All juvenile leaves and twigs are susceptible to infection. Fruit is susceptible until about midsummer.

In humid climates such as that of Florida, these fungal diseases are difficult to control. Protectant fungicides, such as copper products, are still the mainstay of control programs for these diseases (18). However, copper accumulates in soils and can cause phytotoxicity (1). Thus, its use needs to be limited in some plantings. The economics of citrus production preclude frequent application of fungicides. Products such as benomyl and the strobilurin fungicides have post-infectional activity and reduce inoculum production $(5,21)$. However, benomyl has been withdrawn from production by its manufacturer. Strobilurin fungicides recently have been registered for use on citrus and provide good control of scab, melanose, and brown spot (18). However, these fungicides must be managed carefully to avoid future prob- lems with the development of resistance in pathogens.

Induced resistance has been investigated extensively for the control of many plant diseases $(8,11-15,22,26)$. A wide range of compounds such as benzothiadiazoles $(8,13,14)$, salicylic acid (26), harpin protein $(6,22)$, fatty acids, and oligosaccharides $(11,15)$ are known to be effective inducers of plant resistance to disease. In addition, many microorganisms applied to the leaves or roots of plants may induce systemic or local resistance (12). Such resistance is active against many types of organisms such as bacteria, fungi, and even parasitic plants $(6,12,13,15,22)$. Fosetyl-Al and phosphorous acid compounds are highly active against oomycetes and also may act by inducing resistance in the plant (9). These types of compounds also have been shown to have activity against other organisms (10).

Products which induce resistance may be useful in the control of foliar fungal diseases of citrus. It is difficult to control these diseases on rapidly expanding leaves and fruit with protectant fungicides. Induced resistance could provide systemic protection against infection to substitute for or supplement control by standard fungicides.

Some products such as Messenger, ProPhyt, and KeyPlex are registered for use on citrus (18). However, their effects on foliar fungal diseases such as scab, melanose, and Alternaria brown spot are not known. The purpose of the current study was to assess the efficacy of such products to control these diseases under greenhouse conditions and the potential for use of these products in the field.

\section{MATERIALS AND METHODS}

Plant material. Seedlings of rough lemon (Citrus jambhiri Lush) were used for evaluation of products for control of citrus scab. Duncan grapefruit (C. paradisi Macf.) and Dancy tangerine (C. reticulata Blanco) were used to evaluate products for control of melanose and Alternaria brown spot, respectively. Plants were grown in 2.7-liter pots in potting mix as a single stem to a height of 1.0 to $1.5 \mathrm{~m}$. Prior to the initiation of the experiments, plants were trimmed to a height of about $0.7 \mathrm{~m}$, leaving from 15 to 25 leaves on a single stem. Products were applied at various times beginning at bud break and at differ- 
ent stages during the development of shoots. Prior to inoculation, plants were pruned, leaving about three young shoots per plant. Only juvenile tissues are sus- ceptible to attack by citrus scab, melanose, and Alternaria brown spot.

Products. The following products that have been shown or purported to induce
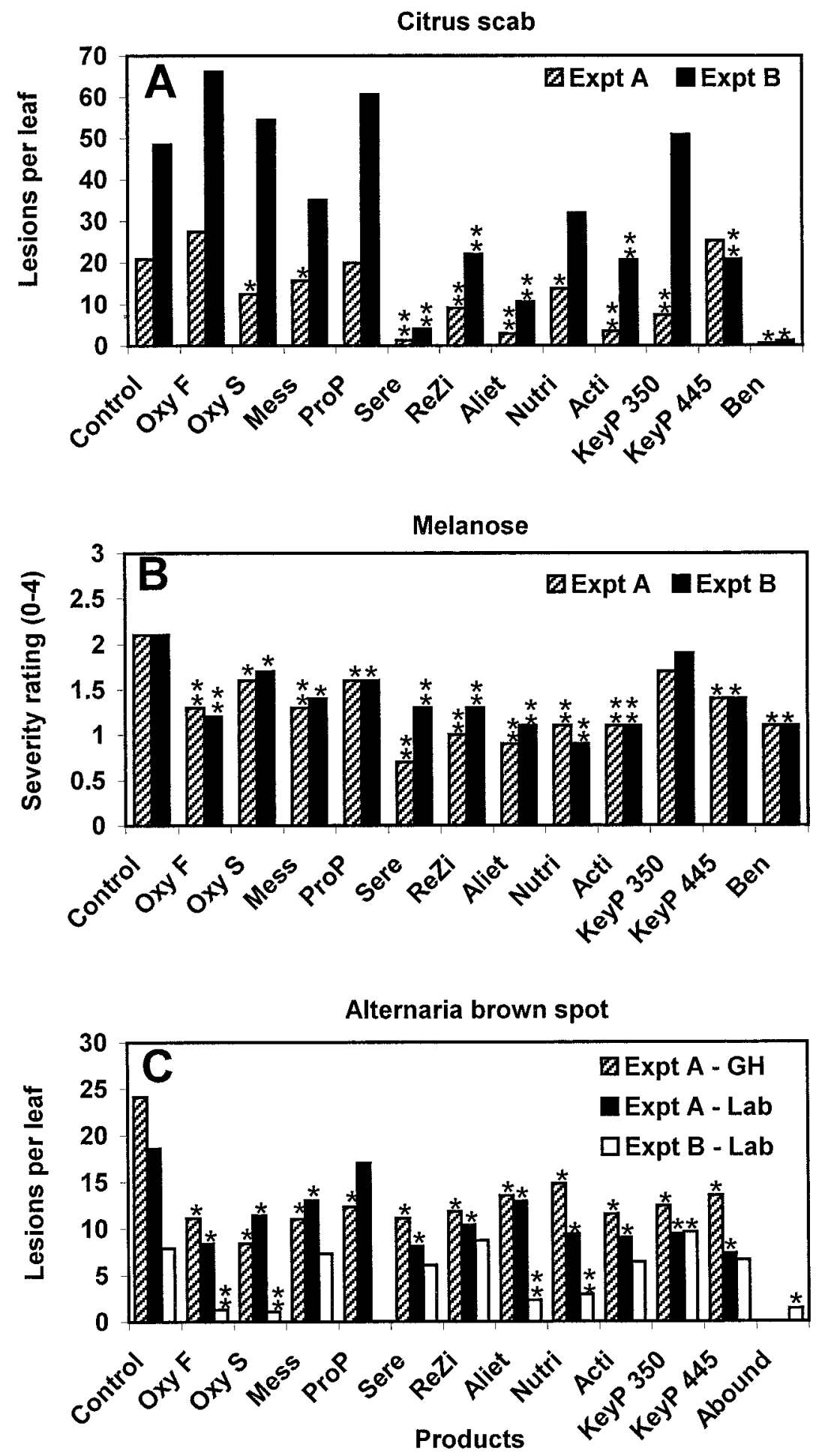

Fig. 1. Effect of resistance-inducing compounds on the severity of: A, citrus scab on rough lemon, B, melanose on grapefruit, and $\mathbf{C}$, Alternaria brown spot on Dancy tangerine. ${ }^{*}=$ Significantly different from the nonsprayed control in the respective experiment, $P \leq 0.05 ; * *=$ not significantly different from the fungicide standard, $P \leq 0.05$; no standard was included in experiment A with Alternaria brown spot; ProPhyt was not included in experiment B. Scab: experiment A conducted May 2001 and B in July 2001; melanose: experiment A, September 2001 and experiment B, November 2001; Alternaria brown spot: experiment A, December 2001 and experiment B, April 2002. Abbreviations: Oxy $\mathrm{F}=$ Oxycom applied as foliar spray, Oxy $\mathrm{S}=$ Oxycom applied as a soil drench, Mess = Messenger, ProP $=$ ProPhyt, Sere $=$ Serenade, ReZi $=$ ReZist, Aliet $=$ Aliette, Nutri $=$ Nutriphite, Acti $=$ Actigard, Key P $350=$ Keyplex 350, Key P $445=$ Keyplex 445, and Ben $=$ Benlate .

resistance in plants were evaluated in greenhouse tests. The manufacturer and the active ingredients or proposed active agents are listed following each: Oxycom Respond in combination with Oxycom Respond Plus (Redox Chemicals, Inc., Burley, ID; hydrogen peroxide), NutriPhite $\mathrm{P}+\mathrm{K}$ (0-28-26) and NutriPhite P (4-30-8) (Biagro Western Sales, Inc., Visalia, CA; phosphorous acid), Messenger (Eden Bioscience, Bothell, WA; harpin protein), Serenade (AgraQuest, Inc., Davis, CA; Bacillus subtilis), Goemar H11 (Goemar, Le Laboratoire de la Mer, Saint-Malo Cedex, France; laminarin), ReZist (Stoller Enterprises, Inc., Houston, TX; undisclosed), KeyPlex 350DP and 445DP (Morse Enterprises, Lts., Miami, FL; alpha-keto acids), Aliette 80WP (Aventis Crop Science, Research Triangle Park, NC; fosetyl-Al), Actigard (Syngenta Crop Protection, Greensboro, NC; acibenzolar-smethyl), and ProPhyt (Luxembourgh Industries, Tel Aviv, Israel; potassium phosphite).

Benlate 50WP (benomyl) was used as a standard fungicide for citrus scab experiments. Abound 2.08F (azoxystrobin) or Benlate was used as a standard for the melanose experiments. For the Alternaria brown spot experiments, either Abound or Headline 2.09F (pyraclostrobin) was used.

Inoculum production. Cultures of $E$. fawcettii were grown on potato dextrose agar (PDA) for 2 to 3 weeks. The procedure of Whiteside (23) was used for production of conidia. Briefly, 2 to 3 small bits of mycelium, about $1 \mathrm{~mm}^{2}$, free of agar, were crushed with a spatula in the bottom of an empty, sterile petri plate and covered with liquid Fries medium containing $5 \mathrm{~g}$ of ammonium tartrate, $1 \mathrm{~g}$ of $\mathrm{NH}_{4} \mathrm{NO}_{3}, 1 \mathrm{~g}$ of $\mathrm{K}_{2} \mathrm{HPO}_{4}, 0.5 \mathrm{~g}$ of $\mathrm{MgSO}_{4}$, $0.03 \mathrm{~g}$ of $\mathrm{CaCl}_{2}, 0.1 \mathrm{~g}$ of $\mathrm{NaCl}$, and $20 \mathrm{~g}$ of sucrose per liter. Mycelium was allowed to grow for 2 days in the dark at $24^{\circ} \mathrm{C}$. The mycelial mat in the bottom of the petri plate then was washed three times with sterile, distilled water and covered with sterile lake water. Plates with mycelium were incubated at room temperature (21 to $24^{\circ} \mathrm{C}$ ) overnight for conidial production. Conidia were suspended in sterile distilled water and the concentration adjusted to about $10^{6}$ per milliliter using a hemacytometer.

Cultures of D. citri were grown on PDA. Bits of mycelium were transferred to plates with autoclaved citrus twigs embedded in PDA. After 2 to 3 weeks, pycnidia with spore tendrils were produced on the twigs. Pycnidia also were produced for some experiments by streaking conidia on PDA plates without twigs. Pycnidia formed directly on the agar surface after 2 to 3 weeks. Conidia exuded from pycnidia were collected and suspended in distilled water. Conidia were washed three times by centrifugation to remove the external mucilage, and the concentration was ad- 
justed to about $10^{6}$ per milliliter. Orange juice was added to the conidial suspension to a final concentration of $1.0 \%(\mathrm{vol} / \mathrm{vol})$ to provide nutrients for germination as described by Whiteside (24).

Cultures of A. alternata were grown on PDA for about 1 week. Small mycelial pieces on about $1 \mathrm{~mm}^{2}$ of agar were transferred to weak PDA (1.2 g of PD broth + agar at $15 \mathrm{~g} /$ liter) and plates were incubated at $24^{\circ} \mathrm{C}$ with $12 \mathrm{~h}$ of light and 12 of $\mathrm{h}$ dark until conidia were produced. Conidia were washed from the plate and filtered through two layers of cheesecloth to remove mycelial fragments. Conidia were washed three times by centrifugation to further remove mycelial fragments and then the concentration was adjusted to about $5 \times 10^{4}$ per milliliter using a hemacytometer.

Inoculations and evaluations. With all three diseases, plants were inoculated by spraying the new foliage to run-off with a conidial suspension using a chromatography sprayer (Crown Spr• Tool; North American Professional Products, Woodstock, IL). Plants were covered with perforated plastic bags and placed in a mist bed in the greenhouse under ambient temperature $\left(20\right.$ to $\left.30^{\circ} \mathrm{C}\right)$ and light conditions. The plants were kept moist for $16 \mathrm{~h}$, then moved to the greenhouse bench for symptom development. For citrus scab, the number of lesions per leaf were counted on three leaves on each of the three shoots of each replicate plant about 7 to 10 days after inoculation. For melanose, symptoms were rated on a scale of 0 to 4 , where $0=$ none, $1=1$ to 10 lesions per leaf, $2=11$ to 100 lesions, $3=101$ to 1,000 lesions, and 4 $=$ confluent lesions at 2 to 3 weeks after inoculation. Results were expressed as the average number of lesions or the average rating per leaf.

For Alternaria brown spot, the number of lesions per leaf was counted as with citrus scab, except that counts were made 3 to 4 days after inoculation. In addition to the greenhouse inoculations, two to four young leaves about $2 \mathrm{~cm}$ long were removed from each replicate plant and placed upright with the petioles immersed in water in 1.5-ml microfuge tubes. Tubes were covered and the leaves positioned by wrapping the top of the tubes around the base of the leaf with parafilm. The vials were placed in a rack in a humid chamber at $100 \%$ relative humidity and then sprayed with conidia. The number of lesions was counted after 2 to 3 days and data were expressed as the average number of lesions per leaf.

Experimental design and statistical analysis. The materials evaluated and the rates used are given in the tables for many experiments. The times of applications in relation to inoculation for each experiment are presented in the tables as well, and dates for each experiment are presented in the text or tables.

Rates, timings of application, and results of some experiments are not presented in tables.

Scab. Goemar H11 in experiment A (April 2000) was applied at $1 \mathrm{mg} / \mathrm{liter} 7$ days before inoculation; at $2 \mathrm{mg} / \mathrm{liter} 4,7$, 10 , or 14 days before inoculation; and at 5 $\mathrm{mg} / \mathrm{liter} 7$ days before inoculation. In experiment B (September 2000), this product was applied at $5 \mathrm{mg} / \mathrm{liter}$ at 3 and 7 days before inoculation; at $5 \mathrm{mg} / \mathrm{liter}$ at 3,7 , and 10 days before inoculation; at $10 \mathrm{mg} / \mathrm{liter} 7$ days before inoculation; and at $50 \mathrm{mg} / \mathrm{liter}$ 7 days before inoculation.

Melanose. Messenger was applied at $0.67 \mathrm{~g} /$ liter or at $1.3 \mathrm{~g} /$ liter 5 days before inoculation or applied at $0.67 \mathrm{~g} /$ liter 5 and 15 days preinoculation in experiment $\mathrm{A}$ (August 2000). In experiment B (September 2000), Messenger was applied at 0.67 or $1.3 \mathrm{~g} /$ liter 5 days preinoculation, at 0.67 or $1.3 \mathrm{~g} /$ liter 5 and 15 days preinoculation, or at $1.3 \mathrm{~g} /$ liter 1 and 8 days preinoculation.

Alternaria brown spot. The combination of Oxycom Respond Plus and Oxycom was applied at $6.3 \mathrm{ml} / \mathrm{liter}$ each 4 and 8 days preinoculation alone, in combination with Nutriphite $4-30-8$ at $5.0 \mathrm{ml} / \mathrm{liter} 8$ days preinoculation, or in combination with Nutriphite $4-30-8$ at $5.0 \mathrm{ml} / \mathrm{liter} 6$ and 13 days preinoculation. This experiment was conducted twice (August and September 2000). In a single Alternaria brown spot experiment, Messenger was evaluated at 0.67 or $1.3 \mathrm{~g} /$ liter applied 5 days preinoculation, at the same rates applied 5 and 18 days preinoculation (July 2000), or at
$1.3 \mathrm{~g} /$ liter 1 and 18 days preinoculation (August 2000).

Comprehensive experiments were conducted involving a wide range of products in two experiments with citrus scab, melanose, and Alternaria brown spot. In these experiments, Oxycom was applied as Oxycom Respond Plus (1.2 ml/liter) + Oxycom Respond $(1.2 \mathrm{ml} /$ liter $)$ as a foliar spray or at $100 \mathrm{ml} /$ pot as a soil drench. All others were applied as foliar sprays at the following rates per liter: Messenger, $1.3 \mathrm{~g}$; ProPhyt, $2.5 \mathrm{ml}$; Serenade, $29 \mathrm{~g}$; ReZist, $2.5 \mathrm{ml}$; Aliette 80WP, $2 \mathrm{~g}$; Nutriphite 4-267, $5 \mathrm{ml}$; Actigard, $0.1 \mathrm{~g}$; Keyplex 350DP, 4 $\mathrm{ml}$; Keyplex 445DP, $4 \mathrm{ml}$; Benlate 50WP, $1.2 \mathrm{~g}$; and Abound, $0.94 \mathrm{ml}$. With citrus scab in these experiments (Fig. 1A), all products were applied twice, at bud break and 10 days before inoculation in experiment $\mathrm{A}$ and 11 days before in experiment $\mathrm{B}$, as well as 5 days before inoculation in both experiments. With melanose in these experiments (Fig. 1B), all products were applied twice, at bud break and 14 days before inoculation in experiment $\mathrm{A}$ and 12 days before inoculation in experiment $\mathrm{B}$, as well as 5 days before in both experiments. With Alternaria brown spot (Fig. 1C), all products were applied at bud break and 11 days before inoculation in both experiments, as well as 5 days before inoculation in experiment $\mathrm{A}$ and 3 days before in experiment B.

In all experiments, each treatment was replicated on five to eight seedlings. In most cases, data are the averages of three leaves on each of three shoots per plant Most experiments were repeated at least once. The results were variable; therefore, the data from each experiment are presented separately. All data were subjected to analysis of variance and mean separation was by the Waller-Duncan $k$-ratio $t$ test, $P$ $\leq 0.05$.

\section{RESULTS}

Citrus scab. Oxycom with or without Nutriphite significantly reduced scab severity when applied before and after inoculation in experiment $\mathrm{A}$ and when applied before inoculation in experiment $\mathrm{D}$ (Table 1). However, none of the Oxycom treatments was effective in reducing scab

Table 1. Effect of Oxycom and Nutriphite on development of citrus scab on rough lemon seedlings ${ }^{\mathrm{w}}$

\begin{tabular}{|c|c|c|c|c|c|c|c|c|c|}
\hline \multirow[b]{2}{*}{ Products } & \multirow[b]{2}{*}{ Rate/liter $^{\mathrm{x}}$} & \multicolumn{2}{|c|}{ Exp. A (December 1999) } & \multicolumn{2}{|c|}{ Exp. B (January 2000) } & \multicolumn{2}{|c|}{ Exp. C (January 2000) } & \multicolumn{2}{|c|}{ Exp. D (March 2000) } \\
\hline & & DBIy & $\overline{\text { Lesions/leaf }}$ & DBIy & Lesions/leaf & DBIy & Lesions/leaf & DBIy & Lesions/leaf \\
\hline Control & & & $11.5 \mathrm{a}^{\mathrm{z}}$ & & $3.7 \mathrm{ab}$ & & $13.9 \mathrm{a}$ & & $45.3 \mathrm{a}$ \\
\hline Oxycom & $6 \mathrm{ml}+6 \mathrm{ml}$ & -10 & $5.8 \mathrm{~b}$ & -11 & $2.6 \mathrm{~b}$ & -12 & $13.8 \mathrm{a}$ & -8 & $22.0 \mathrm{bc}$ \\
\hline $\begin{array}{l}\text { + Nutriphite } 4-30-8 \\
\text { Oxycom }\end{array}$ & $\begin{array}{l}+5.0 \mathrm{ml} \\
6 \mathrm{ml}+6 \mathrm{ml}\end{array}$ & $\begin{array}{l}\cdots \\
-10,-3,+5\end{array}$ & $0.9 \mathrm{c}$ & $\begin{array}{l}\cdots \\
-11,-3,+3\end{array}$ & $3.4 \mathrm{ab}$ & $\begin{array}{l}\cdots \\
-12,-6\end{array}$ & $\begin{array}{c}\ldots \\
13.2 \mathrm{a}\end{array}$ & $\begin{array}{l}\cdots \\
-8,-1\end{array}$ & $25.0 \mathrm{~b}$ \\
\hline $\begin{array}{l}\text { Oxycom } \\
+ \text { Nutriphite } 4-30-8\end{array}$ & $\begin{array}{l}6 \mathrm{ml}+6 \mathrm{ml} \\
+5.0 \mathrm{ml}\end{array}$ & $\begin{array}{l}\cdots \\
-10,-3,+5\end{array}$ & $0.9 \mathrm{c}$ & $-11,-3,+3$ & $4.7 \mathrm{a}$ & $-12,-6$ & $12.2 \mathrm{a}$ & $\begin{array}{l}-8,-1 \\
\ldots\end{array}$ & $\begin{array}{l}16.0 \mathrm{bc} \\
\ldots\end{array}$ \\
\hline Benlate 50WP & $2.1 \mathrm{~g}$ & $-10,-3,+5$ & $0.0 \mathrm{c}$ & $-11,-3,+3$ & $0.0 \mathrm{c}$ & $-12,-6$ & $0.4 \mathrm{~b}$ & $-8,-1$ & $0.8 \mathrm{~d}$ \\
\hline
\end{tabular}

${ }^{w}$ Seedlings were pruned to force new growth and products applied to new young leaves before and/or after inoculation.

${ }^{x} 6 \mathrm{ml}+6 \mathrm{ml}=6 \mathrm{ml}$ each of Oxycom Respond Plus and Oxycom Respond.

y DBI = days before $(-)$ or after (+) inoculation; the first application was made at bud break.

${ }^{\mathrm{z}}$ Mean separation by the Waller-Duncan $k$-ratio $t$ test, $P \leq 0.05$. 
severity in experiments B and C. Benlate experiments.

Messenger applied prior to inoculation in experiment A failed to reduce scab severity significantly (Table 2 ). However, in experiment $\mathrm{B}$, where Messenger was applied 1 and 8 days prior to inoculation, it greatly reduced scab severity. Benlate was not effective in experiment $\mathrm{A}$, but reduced scab in experiment B.

Goemar H11 applied as described did not significantly reduce scab severity in either of the experiments (data not shown).

Serenade applied prior to inoculation was effective in reducing scab when disease severity was low in experiment A, but not in experiment $\mathrm{B}$, where severity was higher (Table 3). Benlate was effecwas highly effective in reducing scab in all

tive in reducing scab severity in both experiments.

ReZist was effective in reducing scab severity in experiment $\mathrm{A}$, but less effective in experiment B (Table 4). Multiple applications appeared to reduce scab severity more than a single spray, but the high rate was no more effective than the low rate. Benlate was effective in both experiments.

Selected rates and timings of materials tested previously as well as additional products were evaluated in larger experiments (Fig. 1A). The products that significantly reduced scab severity compared with the nonsprayed control in both experiments were Serenade, ReZist, Aliette, Actigard, and the standard fungicide Benlate. KeyPlex 350DP and 445DP, soil-applied Oxycom, Messenger, and Nutriphite were

Table 2. Effect of Messenger on the development of citrus scab on rough lemon seedlings ${ }^{\mathrm{x}}$

\begin{tabular}{lcccccc}
\hline & & \multicolumn{2}{c}{ Exp. A (May 2000) } & & \multicolumn{2}{c}{ Exp. B (August 2000) } \\
\cline { 3 - 4 } Product & Rate/liter & \multicolumn{2}{c}{ DBIy } & Lesions/leaf & & \multicolumn{2}{c}{ DBIy } & Lesions/leaf \\
\hline Control & $\ldots$ & $\ldots$ & $25.0 \mathrm{abc}^{\mathrm{z}}$ & & $\ldots$ & $45.3 \mathrm{a}$ \\
Messenger & $0.67 \mathrm{~g}$ & $-10,-5$ & $16.8 \mathrm{abc}$ & & $\ldots$ & $\ldots$ \\
Messenger & $0.67 \mathrm{~g}$ & -10 & $34.5 \mathrm{a}$ & & $\ldots$ & $\ldots$ \\
Messenger & $0.67 \mathrm{~g}$ & -5 & $14.2 \mathrm{bc}$ & & $\ldots$ & $\ldots .6 \mathrm{~b}$ \\
Messenger & $1.3 \mathrm{~g}$ & -10 & $28.5 \mathrm{ab}$ & & $-8,-1$ & $\ldots$ \\
Messenger & $1.3 \mathrm{~g}$ & -5 & $8.5 \mathrm{c}$ & & $\ldots$ & $\ldots$ \\
Benlate 50WP & $1.2 \mathrm{~g}$ & -5 & $9.7 \mathrm{c}$ & $\ldots$ & $0.8 \mathrm{~b}$ \\
Benlate 50WP & $2.1 \mathrm{~g}$ & $\ldots$ & $\ldots$ & $-8,-1$ & $\ldots$
\end{tabular}

$\mathrm{x}$ Seedlings were pruned to force new growth and products applied to new young leaves before inoculation.

${ }^{\mathrm{y}} \mathrm{DBI}=$ days before inoculation; the first application was made at bud break.

${ }^{\mathrm{z}}$ Mean separation by the Waller-Duncan $k$-ratio $t$ test, $P \leq 0.05$.

Table 3. Effects of Serenade on development of citrus scab on rough lemon seedlings ${ }^{\mathrm{x}}$

\begin{tabular}{lcccccc}
\hline & & \multicolumn{2}{c}{ Exp. A (August 2000) } & & \multicolumn{2}{c}{ Exp. B (November 2000) } \\
\cline { 3 - 4 } Product & Rate/liter & \multicolumn{1}{c}{ DBI } & Lesions/leaf & & \multicolumn{1}{c}{ DBI } & Lesions/leaf \\
\hline Control & $\ldots$ & $\ldots$ & $5.9 \mathrm{a}^{\mathrm{z}}$ & & $\ldots$ & $49.8 \mathrm{a}$ \\
Serenade & $14.5 \mathrm{~g}$ & $-13,-5$ & $1.7 \mathrm{~b}$ & & $-15,-5$ & $24.4 \mathrm{ab}$ \\
Serenade & $14.5 \mathrm{~g}$ & -5 & $2.2 \mathrm{ab}$ & & -5 & $59.0 \mathrm{a}$ \\
Serenade & $29.0 \mathrm{~g}$ & $-13,-5$ & $2.9 \mathrm{ab}$ & & $-15,-5$ & $35.8 \mathrm{ab}$ \\
Serenade & $29.0 \mathrm{~g}$ & $-13,-1$ & $0.1 \mathrm{~b}$ & & $-15,-1$ & $26.1 \mathrm{ab}$ \\
Serenade & $29.0 \mathrm{~g}$ & -5 & $1.5 \mathrm{~b}$ & & -5 & $25.0 \mathrm{ab}$ \\
Benlate 50WP & $1.2 \mathrm{~g}$ & $-13,-5$ & $1.4 \mathrm{~b}$ & & $-15,-5$ & $13.1 \mathrm{~b}$ \\
\hline
\end{tabular}

${ }^{\mathrm{x}}$ Seedlings were pruned to force new growth and products applied to new young leaves before inoculation.

${ }^{\mathrm{y}} \mathrm{DBI}=$ days before inoculation; the first application was made at bud break.

${ }^{\mathrm{z}}$ Mean separation by the Waller-Duncan $k$-ratio $t$ test, $P \leq 0.05$.

Table 4. Effects of ReZist on development of citrus scab on rough lemon seedlings ${ }^{\mathrm{x}}$

\begin{tabular}{|c|c|c|c|c|c|}
\hline \multirow[b]{2}{*}{ Product } & \multirow[b]{2}{*}{ Rate/liter } & \multicolumn{2}{|c|}{ Exp. A (April 2001) } & \multicolumn{2}{|c|}{ Exp. B (April 2001) } \\
\hline & & DBI $^{y}$ & Lesions/leaf & DBI $^{\mathbf{y}}$ & Lesions/leaf \\
\hline Control & & & $24.9 \mathrm{a}^{\mathrm{z}}$ & $\ldots$ & $26.7 \mathrm{a}$ \\
\hline ReZist & $2.5 \mathrm{ml}$ & -14 & $14.6 \mathrm{abc}$ & $\ldots$ & \\
\hline ReZist & $2.5 \mathrm{ml}$ & $\ldots$ & 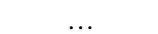 & -5 & $25.6 \mathrm{a}$ \\
\hline ReZist & $2.5 \mathrm{ml}$ & $-14,-5$ & $10.8 \mathrm{bcd}$ & $-12,-5$ & $18.3 \mathrm{abc}$ \\
\hline ReZist & $2.5 \mathrm{ml}$ & $-14,-5,+1$ & $5.8 \mathrm{~cd}$ & $-12,-5,+1$ & $16.7 \mathrm{abc}$ \\
\hline ReZist & $5.0 \mathrm{ml}$ & -14 & $19.0 \mathrm{ab}$ & $\ldots$ & $\ldots$ \\
\hline ReZist & $5.0 \mathrm{ml}$ & -5 & $\ldots$ & -5 & $21.6 \mathrm{ab}$ \\
\hline ReZist & $5.0 \mathrm{ml}$ & $-14,-5$ & $9.3 \mathrm{bcd}$ & $-12,-5$ & $11.5 \mathrm{bc}$ \\
\hline Benlate 50WP & $1.2 \mathrm{~g}$ & $-14,-5$ & $1.5 \mathrm{~d}$ & $-12,-5$ & $5.9 \mathrm{c}$ \\
\hline
\end{tabular}

${ }^{x}$ Seedlings were pruned to force new growth and products applied to new young leaves before inoculation.

${ }^{\mathrm{y}} \mathrm{DBI}=$ days before $(-)$ or after $(+)$ inoculation; the first application was made at bud break.

${ }^{\mathrm{z}}$ Mean separation by the Waller-Duncan $k$-ratio $t$ test, $P \leq 0.05$. effective in one experiment but not in the other. Serenade, ReZist, Aliette, and Actigard were as effective as Benlate in both experiments. Nutriphite and KeyPlex 350DP caused chlorotic and necrotic spotting on young leaves of treated rough lemon seedlings.

Melanose. Serenade reduced melanose severity in experiment A only when applied at the high rate 1 day before inoculation (Table 5). However, in experiment B, all rates and timings were effective in reducing melanose severity. Abound was not effective in experiment A but reduced severity in experiment $\mathrm{B}$.

ReZist reduced melanose severity in experiment A only when applied twice at the highest rate (Table 6). All timings and rates of ReZist significantly reduced melanose severity in experiment B. Abound was highly effective in both experiments.

Messenger applied at the rates and timings described did not significantly reduce melanose severity in either experiment (data not shown).

In the more comprehensive experiments involving previously tested and additional products, all materials except KeyPlex 350DP significantly reduced melanose severity in both experiments compared with the nonsprayed control (Fig. 1B). Foliar-applied Oxycom, Serenade, ReZist, Aliette, Nutriphite, and Actigard reduced disease severity as much as Benlate did. Nutriphite and KeyPlex 350DP caused chlorotic and necrotic spotting on young leaves of grapefruit seedlings.

Alternaria brown spot. In experiments with ReZist, Alternaria brown spot was not controlled in greenhouse evaluations using different rates and application timings in experiment A (Table 7). However, in laboratory assays in the same experiment, ReZist was effective in treatments where at least two applications were made. Again, in greenhouse evaluations of ReZist in experiment $\mathrm{B}$, all treatments involving at least two applications significantly reduced disease. In the laboratory evaluations in the same experiment, only the treatment with three applications was effective. Abound, applied twice, reduced brown spot in most experiments and assays.

Oxycom applied as described did not reduce the severity of Alternaria brown spot in either of two experiments in greenhouse or laboratory evaluations (data not shown). Several treatments using Messenger did not significantly reduce brown spot in either greenhouse or laboratory evaluations in one experiment (data not shown).

In the more comprehensive experiments, nearly all of the products reduced brown spot severity in experiment A (Fig. 1C) in the greenhouse assay. In the laboratory assay, ProPhyt was not effective, but all other products were. In experiment B, only laboratory evaluations were conducted. Foliar and soil applications of Oxycom, Aliette, Nutriphite, and the standard fungi- 
cide Abound significantly reduced disease severity compared with the nonsprayed control. Oxycom applied as a foliar spray or soil drench, Aliette, and Nutriphite were as effective in this experiment as Abound.

\section{DISCUSSION}

Most of the products evaluated that presumably induced resistance in plants provided some degree of control of the citrus diseases studied. We made no attempt to differentiate systemic activity from protective activity in these tests. However, the effective products that were applied only at bud break, when the shoots subsequently inoculated were less than $1 \mathrm{~cm}$ in length, and controlled disease must have had systemic activity. For example, Oxycom + Nutriphite applied only at bud break significantly reduced scab in 2 of 4 tests (Table 1). ReZist applied at bud break only reduced melanose in 1 of 2 tests (Table 7). Applications that were made 5 days prior to inoculation and controlled disease may have had systemic or protectant activity. Products such as Serenade were much more effective when applied 1 day prior to inoculation for control of scab (Table 3) and melanose (Table 6). Thus, most of the effectiveness of this product probably was due to its protective activity, which is based presumably on antagonistic effects of Bacillus subtilis on germinating fungal spores rather than induction of host defense responses.

The phenomenon of induced resistance has been extensively investigated in plants $(8,11,12,14,15,22,26)$, and new experimen-

Table 5. Effects of Serenade on development of melanose on grapefruit seedlings ${ }^{\mathrm{x}}$

\begin{tabular}{|c|c|c|c|c|c|}
\hline \multirow[b]{2}{*}{ Product } & \multirow[b]{2}{*}{ Rate/liter } & \multicolumn{2}{|c|}{ Exp. A (October 2000) } & \multicolumn{2}{|c|}{ Exp. B (October 2000) } \\
\hline & & DBI $^{\mathbf{y}}$ & Severity rating $(0-4)$ & DBI ${ }^{y}$ & Severity rating $(0-4)$ \\
\hline Control & $\ldots$ & $\ldots$ & $1.7 \mathrm{ab}^{\mathrm{z}}$ & $\ldots$ & $2.1 \mathrm{a}$ \\
\hline Serenade & $14.5 \mathrm{~g}$ & -5 & $1.5 \mathrm{abc}$ & -5 & $0.9 \mathrm{~cd}$ \\
\hline Serenade & $14.5 \mathrm{~g}$ & $-11,-5$ & $1.7 \mathrm{ab}$ & $-12,-5$ & $1.5 \mathrm{~b}$ \\
\hline Serenade & $29.0 \mathrm{~g}$ & -5 & $1.8 \mathrm{ab}$ & $\ldots$ & $\ldots$ \\
\hline Serenade & $29.0 \mathrm{~g}$ & $-11,-5$ & $1.8 \mathrm{ab}$ & $-12,-5$ & $1.4 \mathrm{bc}$ \\
\hline Serenade & $29.0 \mathrm{~g}$ & $-11,-1$ & $1.0 \mathrm{c}$ & $-12,-1$ & $0.4 \mathrm{e}$ \\
\hline Abound 2.08EC & $1.0 \mathrm{ml}$ & $-15,-5$ & $1.2 \mathrm{bc}$ & $-12,-5$ & $0.8 \mathrm{de}$ \\
\hline
\end{tabular}

$\mathrm{x}$ Seedlings were pruned to force new growth and products applied to new young leaves before inoculation.

y $\mathrm{DBI}=$ days before inoculation; the first application was made at bud break.

${ }^{\mathrm{z}}$ Mean separation by the Waller-Duncan $k$-ratio $t$ test, $P \leq 0.05$.

Table 6. Effects of ReZist on development of melanose on grapefruit seedlings

\begin{tabular}{|c|c|c|c|c|c|}
\hline \multirow[b]{2}{*}{ Product } & \multirow[b]{2}{*}{ Rate/liter } & \multicolumn{2}{|c|}{ Exp. A (June 2001) } & \multicolumn{2}{|c|}{ Exp. B (August 2001) } \\
\hline & & DBI ${ }^{y}$ & Severity rating $(0-4)$ & DBI ${ }^{y}$ & Severity rating $(0-4)$ \\
\hline Control & & $\cdots$ & $0.6 \mathrm{a}^{\mathrm{z}}$ & $\ldots$ & $2.2 \mathrm{a}$ \\
\hline ReZist & $2.5 \mathrm{ml}$ & -10 & $0.4 \mathrm{ab}$ & -12 & $1.5 \mathrm{~b}$ \\
\hline ReZist & $2.5 \mathrm{ml}$ & $-10,-5$ & $0.5 \mathrm{ab}$ & $-12,-5$ & $0.7 \mathrm{~d}$ \\
\hline ReZist & $2.5 \mathrm{ml}$ & $-10,-5,+1$ & $0.3 \mathrm{ab}$ & $-12,-5,+1$ & $0.7 \mathrm{~d}$ \\
\hline ReZist & $5.0 \mathrm{ml}$ & -10 & $0.4 \mathrm{ab}$ & -12 & $1.2 \mathrm{bc}$ \\
\hline ReZist & $5.0 \mathrm{ml}$ & $-10,-5$ & $0.2 \mathrm{~b}$ & $-12,-5$ & $0.9 \mathrm{~cd}$ \\
\hline Abound 2.08EC & $0.94 \mathrm{ml}$ & $-10,-5$ & $0.2 \mathrm{~b}$ & $-12,-5$ & $0.2 \mathrm{e}$ \\
\hline
\end{tabular}

${ }^{x}$ Seedlings were pruned to force new growth and products applied to new young leaves before and/or inoculation.

${ }^{\mathrm{y}} \mathrm{DBI}=$ days before $(-)$ or after (+) inoculation; the first application was made at bud break.

${ }^{\mathrm{z}}$ Mean separation by the Waller-Duncan $k$-ratio $t$ test, $P \leq 0.05$. tal and commercial products have been generated based on that research. Many of those products are now being evaluated and compared with standard fungicides for control of fruit diseases $(2-7,13)$. Fosetyl$\mathrm{Al}$ and phosphorous acid products have been extensively evaluated for control of diseases caused by Phytophthora spp. and other oomycetes. However, very limited information is available on the use of these products for control of diseases caused by other pathogens (10).

Most of the induced-resistance products evaluated for control of diseases of other crops have provided significant reduction in disease $(2-4,7,16)$. However, control generally was less effective than that achieved with standard fungicides, and less consistent. Our experience is similar with most of these products for control of foliar fungal diseases of citrus. In our tests, the products that were most consistently effective were ReZist, Actigard, fosetyl-Al (Aliette), and some phosphorous acid products. Oxycom and Messenger provided good control of scab in some tests, but were not consistently effective. Oxycom appeared least effective in tests conducted during cool weather in January. Serenade significantly reduced disease severity of scab, melanose, and brown spot in at least some of the treatment regimes. Most other products resulted in limited or erratic control of these citrus diseases. In some cases, induced-resistance products provided control as good as that achieved with standard fungicides. However, the level and consistency of control was significantly less than with standard products.

Even though induced resistance products are not highly effective for disease control, they may be useful in an integrated program with standard fungicides. With the three diseases considered here, it is important to control infection on the spring growth. With scab and Alternaria brown spot, infection of leaves in the spring results in inoculum buildup that makes the disease difficult to control on fruit later in the season. With melanose, this is less of a factor, but infected twigs eventually may serve as inoculum sources. Scab and

Table 7. Effects of ReZist on the development of Alternaria brown spot on Dancy tangerine seedlings under greenhouse conditions (GH) and on detached leaves in the laboratory $(\mathrm{Lab})^{\mathrm{x}}$

\begin{tabular}{|c|c|c|c|c|c|c|c|}
\hline \multirow[b]{3}{*}{ Product } & \multirow[b]{3}{*}{ Rate/liter } & \multicolumn{6}{|c|}{ Lesions/leaf } \\
\hline & & \multicolumn{3}{|c|}{ Exp. A (May 2001) } & \multicolumn{3}{|c|}{ Exp. B (June 2001) } \\
\hline & & DBI $^{y}$ & GH & Lab & DBI $^{y}$ & GH & Lab \\
\hline Control & $\ldots$ & $\ldots$ & $10.4 \mathrm{ab}^{\mathrm{z}}$ & $12.7 \mathrm{a}$ & $\ldots$ & $8.2 \mathrm{a}$ & $6.2 \mathrm{a}$ \\
\hline ReZist & $2.5 \mathrm{ml}$ & -14 & $13.0 \mathrm{a}$ & $3.0 \mathrm{~b}$ & -12 & $8.9 \mathrm{a}$ & $6.7 \mathrm{a}$ \\
\hline ReZist & $2.5 \mathrm{ml}$ & $-14,-5$ & $2.0 \mathrm{~b}$ & $3.6 \mathrm{~b}$ & $-12,-5$ & $2.6 \mathrm{~b}$ & $6.4 \mathrm{a}$ \\
\hline ReZist & $2.5 \mathrm{ml}$ & $-14,-5,+1$ & $5.0 \mathrm{ab}$ & $3.4 \mathrm{~b}$ & $-12,-5,+1$ & $3.5 \mathrm{~b}$ & $1.7 \mathrm{~b}$ \\
\hline ReZist & $5.0 \mathrm{ml}$ & -14 & $8.2 \mathrm{ab}$ & $13.7 \mathrm{a}$ & -12 & $6.6 \mathrm{a}$ & $8.1 \mathrm{a}$ \\
\hline ReZist & $5.0 \mathrm{ml}$ & $-14,-5$ & $4.2 \mathrm{~b}$ & $6.0 \mathrm{~b}$ & $-12,-5$ & $2.8 \mathrm{~b}$ & $5.7 \mathrm{a}$ \\
\hline Abound 2.08EC & $0.94 \mathrm{ml}$ & $-14,-5$ & $2.5 \mathrm{~b}$ & $3.9 \mathrm{~b}$ & $-12,-5$ & $2.1 \mathrm{~b}$ & $0.6 \mathrm{~b}$ \\
\hline
\end{tabular}

x Seedlings were pruned to force new growth and products applied to new young leaves before inoculation.

y $\mathrm{DBI}=$ days before $(-)$ or after (+) inoculation; the first application was made at bud break.

${ }^{\mathrm{z}}$ Mean separation by the Waller-Duncan $k$-ratio $t$ test, $P \leq 0.05$. 
Alternaria brown spot are difficult to control on rapidly expanding leaves and would require frequent fungicide application (18). Benomyl has excellent eradicant as well as post-infectional kickback action for control of scab $(5,21)$. However, with the loss of that product, only copper fungicides, ferbam, and strobilurins are registered for use on citrus (18). Induced-resistance products could be applied when shoots first form in the spring to provide at least some protection during the time of rapid leaf expansion. Protectant products could be applied later after growth has slowed.

Fosetyl-Al and phosphorous acid products are widely used in Florida citrus for control of Phytophthora foot and root rot (18). Timing of such applications is not critical. Thus, it may be possible to apply these products for Phytophthora control at an appropriate time for scab, Alternaria brown spot, or melanose control and achieve some additional benefit.

\section{ACKNOWLEDGMENTS}

We thank AgraQuest, Eden Bioscience, Goemar, Redox Chemicals, and Stoller Enterprises for financial support for the project; and A. J. Tesoriero and A. Bhatia for technical assistance.

\section{LITERATURE CITED}

1. Alva, A. K., and Graham, J. H. 1991. The role of copper in citriculture. Adv. Agron. 1:145-170.

2. Bervejillo, J., Bhatt, M. S., and Gubler, W. D. 2000. Evaluation of fungicides for control of grape powdery mildew, 1999. Fungic. Nematicide Tests 55:94-95

3. Bhaskara, M. V., Norelli, J. L., and Aldwinckle, H. S. 2000. Control of fire blight infection of apple blossoms, 1999. Fungic. Nematicide Tests 55:22.

4. Bhaskara Reddy, M. V., Norelli, J. L., and Aldwinckle, H. S. 2001. Biologicals, SAR inducers, copper compounds and other chemicals for blossom blight control on apple, 2000. Fungic. Nematicide Tests 2001. On-line Rep. No. PF 34.

5. Bushong, P. M., and Timmer, L. W. 2000. Evaluation of postinfection control of citrus scab and melanose with benomyl, fenbuconazole, and azoxystrobin. Plant Dis. 84:12461249.

6. de Capdeville, G., Beer, S. V., Wilson, C. L., and Aist, J. R. 2001. Blue mold decay of apples reduced by post-harvest treatment with harpin. (Abstr.) Phytopathology 91:S193.

7. Everts, K. L., Shields, P. L., and Armentrout, D. K. 2001. Evaluation of fungicides for managing gummy stem blight and anthracnose on watermelon, 2000. Fungic. Nematicide Tests On-line Rep. No. V115.

8. Gorlach, J., Volrath, S., Oostendorp, M., Kogel, K.-H., Beckhove, U., Staub, T., Ward, E., Kessmann, H., and Ryals, J. 1996. Benzothiadiazole, a novel class of inducers of systemic acquired resistance, activates systemic resistance in wheat. Plant Cell 8:629-643.

9. Guest, D. I., and Bompeix, G. 1990. The complex mode of action of phosphonates. Austral. Plant Pathol. 19:113-115.

10. Heaton, J. B., and Dullahide, S. R. 1990. Efficacy of phosphonic acid in other host pathogen systems. Austral. Plant Pathol. 19:133-134.

11. Kobayashi, A., Tai, A., Hiroshi, K., and Kazuyoshi, K. 1993. Elicitor-active oligosaccharides from algal laminarin stimulate the production of antifungal compounds in alfalfa. Z. Naturforsch. 48C:575-579.

12. Liu, L., Kloepper, J. W., and Tuzun, S. 1995. Induced systemic resistance in cucumber against bacterial angular spot by plant-growth promoting rhizobacteria. Phytopathology 85:843-847.

13. Matheron, M. E., and Porchas, M. 2002. Suppression of Phytophthora root and crown rot on pepper plants treated with Acibenzolar-SMethyl. Plant Dis. 86:292-297.

14. Narusaka, X., Naraska, M., Horio, T., and Ishii, H. 1999. Comparison of local and systemic-induced resistance in cucumber plants treated with benzothiadiazoles or salicylic acid. Plant Cell Physiol. 40:388-395.

15. Sticher, L., Manch-Mani, B., and Métraux. 1997. Systemic acquired resistance. Annu.
Rev. Phytopathol. 35:235-270.

16. Su, H., and Gables, W. A. 2000. Field evaluation of fungicides for control of Botrytis cinerea on strawberry fruits, Watsonville, CA. 1999. Fungic. Nematicide Tests 55:135-136.

17. Timmer, L. W. 2000. Scab Diseases. Pages 31-32 in: Compendium of Citrus Diseases, 2nd ed. L. W. Timmer, S. M. Garnsey, and J. H. Graham, eds. American Phytopathological Society Press, St. Paul, MN.

18. Timmer, L. W., ed. 2002. 2002 Florida Citrus Pest Management Guide. Univ. Fla. Inst. Food Agric. Sci. Publ. No. SP-43.

19. Timmer, L. W., and Gottwald, T. R. 2000 Greasy spot and similar diseases. Pages 25-28 in: Compendium of Citrus Diseases, 2nd ed. L. W. Timmer, S. M. Garnsey, and J. H. Graham, eds. American Phytopathological Society Press, St. Paul, MN.

20. Timmer, L. W., Solel, Z., and Orozco-Santos, M. 2000. Alternaria brown spot of mandarins. Pages 19-20 in: Compendium of Citrus Diseases. L. W. Timmer, S. M. Garnsey, and J. H. Graham, eds. American Phytopathological Society Press, St. Paul, MN.

21. Timmer, L. W., and Zitko, S. E. 1993. Techniques for greenhouse evaluation of fungicides for control of citrus scab. Pages 125-129 in: Proc. IV Congr. Int. Soc. Citrus Nurserymen. E. Rabe, ed. S. Afr. Citrus Nurserymen's Assoc.

22. Wei, C., Laby, R. J., Zumoff, C. H., Bauer, H. W., He, S. Y., Colmer, A., and Beer, S. V. 1992. Harpin, elictor of the hypersensitive response produced by the plant pathogen $\mathrm{Er}$ winia amylovora. Science 257:1-132.

23. Whiteside, J. O. 1975. Biological characteristics of Elsinoe fawcettii pertaining to the epidemiology of sour orange scab. Phytopathology 65:1170-1175.

24. Whiteside, J. O. 1977. Sites of action of fungicides in the control of citrus melanose. Phytopathology 67:1067-1072.

25. Whiteside, J. O. 2000. Melanose. Pages 28-29 in: Compendium of Citrus Diseases, 2nd ed. L. W. Timmer, S. M. Garnsey, and J. H. Graham, eds. American Phytopathological Society Press, St. Paul, MN.

26. Yalpani, N., and Raskin, I. 1993. Salicylic acid: a systemic signal in induced plant resistance. Trends Microbiol. 1:88-92. 